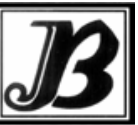

J. bio-sci. 16: 11-14, 2008

ISSN 1023-8654

http://www.banglajol.info/index.php/JBS/index

\title{
A NEW SPECIES OF THE GENUS PHANEROTOMA WESMAEL (BRACONIDAE: CHELONINAE) WITH A KEY TO INDIAN SPECIES
}

\author{
M Sheeba and T C Narendran* \\ Systematic Entomology Laboratory, Department of Zoology, University of Calicut, Kerala- 673635 , India
}

Abstract

A new species of Phanerotoma viz., P. malabarica Sheeba \& Narendran sp. nov. from India is described and compared with its closest relative. A key to Indian species of Phanerotoma is also provided.

Key words: Phanerotoma, Braconidae, Cheloninae, New species, P. malabarica

\section{Introduction}

Wesmael 1838 erected the genus Phanerotoma with the type species Chelonus dentatus Panzer. The genus includes two subgenera: Bracotrictoma Csiki and Phanerotoma Wesmael (Achterberg 1990). It is a cosmopolitan genus characterized by glabrous eyes, 23 segmented antenna, comparatively stout pterostigma and carapace with distinct sutures. The genus is represented by nine species from India (Shenefelt 1973, Zettel 1990, Varshney and Shujauddin 1999 and Ahmad and Shujauddin 2004). In this work we describe one new species of Phanerotoma from Kerala, India. A key to Indian species is also provided.

The terminology used in this work is that of Achterberg (1993). The types of the species described are deposited in Department of Zoology, University of Calicut pending transfer to Western Ghat Regional Station, Zoological Survey of India, Kozhikode, Kerala, India later.

\section{Materials and Methods}

The Braconids were collected using sweep net and curated by the methods described by Narendran (2001). Observations were made under Leica MZ6 Stereozoom Microscope (Switzerland) and the drawings were made using the drawing tube of the same microscope. The drawings were enlarged to appropriate size using the KB enlarger of model B2M.

Key to indian species of the genus Phanerotoma Wesmael

(Modified from Zettel (1990) and Ahmad \& Shujauddin (2004))

1. Apical spine of hypopygium $0.23 x$ length of metasoma P. syedi Ahmad \& Shujauddin

-- Apical spine of hypopygium less than $0.23 x$ length of metasoma

2. Ocellocular line (OOL) less than $2 x \mathrm{OD}: \mathrm{m}$-cu strongly postfurcal................................. indica Zettel

-- OOL greater than $2 \times \mathrm{OD}$; m-cu different

3. Metasoma short and broad, shorter than mesosoma, at most 1.65x its breadth; antenna shorter and thicker than that of other species. P. sylepta Zettel

-- Metasoma much slender

4. Length $3 \mathrm{~mm}$. P. buchneri Fahringer

-- Length greater than $4 \mathrm{~mm}$.

5. Fore wing vein $2-S R$ almost straight.

-- Fore wing vein 2-SR slightly sinuate.

${ }^{*}$ Corresponding author. 
6. Fore wing with $\mathrm{m}$-cu interstitial; malar space $0.86 \mathrm{x}$ basal width of mandible;

$\mathrm{OOL} 4 \mathrm{x}$ Postocellar line (POL)

..p. agarwali Varshney \& Shujauddin

-- Fore wing with $\mathrm{m}$-cu antifurcal; malar space $0.43 \mathrm{x}$ basal width of mandible; OOL 3.3x POL P. hayati Varshney \& Shujauddin

7. Fore wing with $3-S R$ hardly more than $2 x r(1.65-2.1)$;

metasoma of female at least twice its width. P. nathani Zettel

-- Fore wing with 3-SR more than $3 x$ r; metasoma of female less than twice its width.

8. Length 3.9- 4.5mm; clypeus punctate and shiny; scutellar sulcus hardly recognizable; 3-SR 3x r; 2SR+M transverse; 1-R1 1.53x pterostigma; metasoma of female 1.85x its width P. noyesi Zettel -- Length $4.1 \mathrm{~mm}$; clypeus smooth, shiny and hairy; scutellar sulcus wide and crenulate; 3-SR 5.5x r; 2SR+M longitudinal; 1-R1 1.71x pterostigma; metasoma of female 1.67x its width $P$. malabarica Sheeba \& Narendran sp. nov.

Phanerotoma malabarica Sheeba \& Narendran sp. nov.

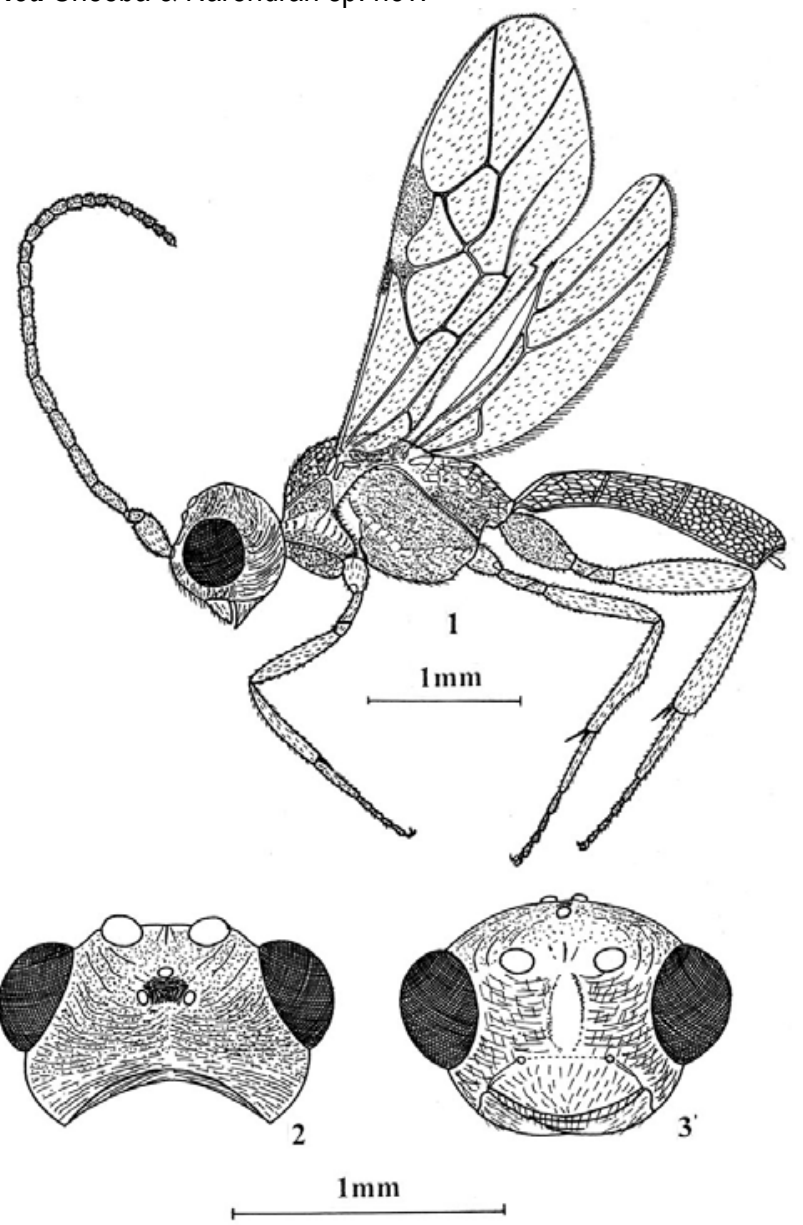

Figs. 1-3 Phanerotoma malabarica Sheeba \& Narendran sp. nov. 1. Body profile, 2. Head dorsal view, 3. Head front view 
Holotype: Female: Length of body $4.1 \mathrm{~mm}$, of antenna $3.48 \mathrm{~mm}$ and of fore wing $3.06 \mathrm{~mm}$.

Head: Width 1.43 and 2.16x its median length in anterior (Fig.3) and dorsal (Fig.2) views respectively; antenna with 23 segments; scape $2 x$ its breadth; length of third, fourth, penultimate and apical antennal segments 3.8, 3.6, 1.67 and 3.25x their width respectively; frons granulose with rugosities on either side of srobe and with median carina (Fig 3); area of stemmaticum rugulose; OOL: diameter of posterior ocellus: $P O L=13: 2: 7$; vertex transversely rugose with fine granulate background anteriorly, rugose posteriorly and hairy; occiput transversely rugose; eyes glabrous, not emarginate; length of eye $1.43 x$ temple in dorsal view; temple finely rugose with fine granulations near eyes; gena rugose; face rugose with median ridge and hairy (Fig 2); width of face 2.18x height; clypeus smooth, shiny and hairy; width 2.79x its height; malarspace rugose, $1.6 \mathrm{x}$ basal width of mandible; mandible long and slender; inner tooth of mandible much longer than that of outer.

Mesosoma (Fig 1): Length 1.57x its height; pronotum coriaceous dorsally with crenulate edges, coriaceous laterally with crenulated middle region; mesoscutum granulose- reticulate, hairy; notauli distinct and foveate anteriorly, absent posteriorly; scutellar sulcus wide and crenulate; scutellum punctuate and hairy; metanotum with median ridge; propleuron coriaceous; mesopleuron granulose, hairy; precoxal sulcus with weak fovea; pleural sulcus crenulate; metapleuron coriaceous; propodeum reticulate with distinct transverse carina and small tubercles. Fore wing 2.6x its width; length of 1-R1 1.7x pterostigma; $r$ emerging much beyond middle of pterostigma; 3-SR 5.5x r; 2-SR slightly sinuate; 3-SR and SR1 straight; $2 \mathrm{SR+M}$ longitudinal; parastigma large and pigmented; maximum width of pterostigma $0.63 x$ length of 3-SR; mid tibia with a blister; mid tibial longer spur $0.46 \mathrm{x}$ mid basitarsus; hind coxa granulate; hind femur $4 \mathrm{x}$ its width; hind tibia $5.25 \mathrm{x}$ width, $1.13 \mathrm{x}$ hind femur; hind basitarsus as long as remaining tarsal segments.

Metasoma (Fig 1): Oval shaped; 1.67x its width; 1.17x mesosoma; first and second tergites longitudinally reticulate but reticulate laterally; first tergite with lateral converging carinae slightly extending its middle; third tergite reticulate- rugose, shallowly emarginate, with slightly protruding corners and its medial length $1.33 x$ medial length of second tergite; ovipositor sheath just protruding beyond apex of metasoma.

Colour: Yellowish brown. Tip of mandible, apical seven segments of antenna, stigma, veins 1-R1, 1-M, 1cu1, cu-a basal half of 2-cu1, r, 3-SR, SR1 and 2-M brown (other veins pale yellow); stemmaticum and eyes black; ocelli shining yellow; hind tibia medially pale yellow.

Male: Unknown.

Host: Unknown.

Material Examined: Holotype: Female, INDIA: Kerala, Malappuram Dt., Manjeri $\left(11^{\circ} 7^{\prime} \mathrm{N} 76^{\circ} 7^{\prime} \mathrm{E}\right), 6$.iii.2005, Sheeba. M. Paratypes: 1 Female with same data of holotype; 2 Females, Alapuzha Dt, Kayankulam, Onattukara $\left(9^{\circ} 10^{\prime} \mathrm{N} 76^{\circ} 30^{\prime} \mathrm{E}\right)$, 19.iv.2005, T. C. Narendran \& party.

Etymology: Named after the area of collection (Malabar area of Kerala State).

\section{Discussion}

The new species closely resembles $P$. noyesy Zettel in having metasoma of female less than twice its width, 2-SR slightly sinuate, and metasoma oval shaped but differs in having: 1) Clypeus smooth, shiny and hairy (In P. noyesy clypeus punctuate and shining ); 2) Mesoscutum granulose- reticulate (In P. noyesy mesoscutum finely rugose); 3) Scutellar sulcus wide and crenulate (In $P$. noyesy scutellar sulcus hardly recognizable); 4) 1-R1 1.71x pterostigma (In P. noyesy 1.53x pterostigma) and 5) Metasoma of female 1.67x its width (In P. noyesy $1.85 \mathrm{x}$ width). 


\section{Acknowledgements}

We are grateful to the authorities of the University of Calicut for providing facilities for this work. One of the authers (MS) thanks CSIR New Delhi for the award of Senior Research Fellowship.

\section{References}

Achterberg C Van (1990) Revision of the Western Palaearctic Phanerotomini (Hymenoptera: Braconidae). Zool. Verh. Leiden 255: 1-360.

Achterberg C Van (1993) Illustrated key to the subfamilies of the Braconidae (Hymenoptera: Ichneumonoidea). Zool. Verh. Leiden 288: 1-189.

Ahmad Z and Shujauddin (2004) Description of a new species of the genus Phanerotoma Wesmael (Hymenoptera: Braconidae) along with a key to Indian species. Zoos' Print Journal. 19(12): 1706-1707.

Shenefelt R D (1973) Hymenopterorum Catalogus. (nov. ed) Part 10, Braconidae 6: 813-936. 's Gravenhage.

Varshney K and Shujauddin (1999) Two new species of the genus Phanerotoma Wesmael (Hymenoptera: Braconidae) from India. Records of Zoological Survey of India 97: 259-263.

Wesmael C (1838) Monographie des braconides de Belgique. Nouv. Mem. Acad. Sci. Brux. 11: 165.

Zettel H (1990) Die Phanerotoma- Arten des indischen subkontinentes (Insecta: Hymenoptera: Braconidae: Cheloninae). Reichenbachia 27: 147-158. 